\title{
O álbum poético em português e em espanhol: sinergia estética entre palavras e ilustrações
}

\author{
SARA RAQUEL DUARTE REIS DA SILVA
}

Universidade do Minho, Braga, Portugal

MOISÉS SELFA SASTRE

Universitat de Lleida, Lérida, Espanha

\section{RESUMO}

Este estudo procurou problematizar a relação textual que se observa entre a palavra e a imagem em um tipo de texto especialmente concebido para crianças: o álbum poético. Para tal, utilizamos alguns exemplos textuais significativos desse subgênero literário/editorial ainda em emergência tanto em Portugal quanto na Espanha, e propusemos uma definição e uma caracterização baseadas no comentário de sequências poéticas nas quais a ilustração sustenta o conteúdo verbal. Efetivamente, centrando a atenção no álbum poético de potencial recepção infanto-juvenil, sugere-se uma análise de diversos títulos de autoria portuguesa e espanhola, assente em uma leitura dialógica do texto verbal e do visual. A sinergia que se concretiza entre as duas componentes enunciadas alicerça essa nova construção estética que tem, na verdade e na sua essência, a poesia como matriz e, em larga medida, é devedora dos efeitos expressivos da metáfora.

PALAVRAS-CHAVE

literatura infantil; poesia infantil; álbum poético; ilustração; metáfora. 


\section{PORTUGUESE AND SPANISH PICTURE POETRY BOOKS: AESTHETIC SYNERGY BETWEEN WORDS AND ILLUSTRATIONS}

\section{ABSTRACT}

This study aimed to discuss the relation between words and images in a type of text especially directed to children: the picture-poetry book. From significant examples of this literary subgenre still emerging in both Portugal and Spain, we propose a definition and characterization based on the review of poetic sequences in which illustrations support the verbal content. By focusing on picture-poetry books potentially aimed for adolescents and children, we present an analysis of several titles by Portuguese and Spanish authors, based on the dialogic reading between verbal and visual texts. The synergy found between these two components creates de foundantions of a new aesthetic construction which, in truth and in essence, has poetry as its matrix and owes its expressive effects to metaphors.

KEYWORDS

children's literature; poetry for children; picture-poetry book; illustration; metaphor.

\section{EL ÁLBUM POÉTICO EN PORTUGUÉS Y EN ESPAÑOL: SINERGIA ESTÉTICA ENTRE PALABRAS E ILUSTRACIONES}

\section{RESUMEN}

Este estudio ha tenido como objetivo discutir la relación textual que existe entre la palabra y la imagen en un tipo texto especialmente creado para niños: el álbum poético. Para ello, utilizamos algunos ejemplos textuales significativos de un subgénero literario en emergencia tanto en Portugal cuanto en España, y hemos propuesto una definición de este subgénero y su caracterización a partir del comentario de secuencias poéticas en las cuales la imagen sustenta el contenido verbal. De hecho, centrando la atención en el álbum poético de potencial recepción infantil y juvenil, proponemos un análisis de diversos títulos de autoría portuguesa y española basado en la lectura dialógica entre el texto verbal y el texto ilustrativo. La sinergia que se establece entre estos dos componentes enunciados facilita una nueva construcción estética que da pie, en su esencia, a un tipo de poesía que, en gran medida, es deudora de los efectos expresivos de la metáfora.

literatura infantil; poesía infantil; álbum poético; ilustración; metáfora. 


\section{DEFINIÇÃO DE ÁLBUM POÉTICO: ALGUMAS CARACTERÍSTICAS SIGNIFICATIVAS}

Em um estudo recente, Nodelman (2008) preconiza que os autores que escrevem para o público infanto-juvenil voltam-se mais à ideia que possuem sobre as crianças e os jovens do que para o que realmente são. Essa ideia pré-concebida e, em certa medida, estereotipada — assunção, nas palavras de Nodelman (2008) —, acerca do potencial leitor de literatura infantil e juvenil (LIJ) é a que, segundo o estudioso, vai configurar uma parte significativa da LIJ atual como um tipo de literatura com determinadas caraterísticas, que possui uma configuração que a diferencia da literatura para adultos. Seguindo esse ponto de vista, a poesia infantil e juvenil do século XXI prossegue mobilizando recursos literários da lírica do século passado - como a rima quase sempre consoante; os versos de arte maior, frequentemente regulares; as imagens que carecem de audácia poética - , além de perpetuar certos temas recorrentes, deixando de lado muitos outros.

Se o que mencionamos até agora pode ser aplicado a um elevado número de textos atuais da poesia para crianças e jovens, não se poderá dizer o mesmo relativamente a um subgênero da lírica infantil — chamemos-lhe assim —, que se encontra a emergir na LIJ do presente: o álbum poético. Trata-se, efetivamente, daquele "tipo" de obra ou de texto em que a leitura de uma única composição poética, ou de um conjunto de poesia glosada a partir de um mesmo motivo, é acompanhada por ilustrações que sustentam o sentido e o interesse do texto (Hanán Díaz, 2007). Referimo-nos a um tipo de leitura na qual a comunicação que se celebra entre o autor do poema e o seu leitor é suportada, de forma determinante, pelo poder que a imagem imprime à palavra e vice-versa (Schritter, 2005). Segundo Silva (2011, p. 565-566),

O diálogo entre um poema, ou melhor, entre as respectivas partes que o estruturam - os versos - e as imagens criadas à sua volta motivadas por aquelas/aqueles, resulta num objecto estético com um elevado grau de coerência e potencialmente fomentador de múltiplas leituras, que podem ser concretizadas ao ritmo pessoal de cada destinatário extratextual, pelo facto do seu conteúdo se estender de forma progressiva, com sobriedade e contenção, formando uma mancha gráfica inovadora.

Apesar de apenas nos anos 1960 se observar na Europa o desenvolvimento do álbum narrativo a um ritmo vertiginoso (Orozco López, 2009), no álbum poético, forma bem mais recente, herdeiro daquele, encontramos igualmente uma arquitetura híbrida, fruto da associação entre os códigos pictórico e verbal, formado por versos livres que, muitas vezes, não rimam entre si. Toda a sua aparência nos impele a equacionar um tipo de texto cuja unidade é a página na qual a ilustração é primordial (Bosch, 2007), podendo chegar a ser mesmo subjacente a ela (Bosch, 2012, p. 75). Nesse novo sugbgênero poético/editorial ocorre o tratamento de temas comuns na poesia (o amor, o mar e o sentido da existência, por exemplo), a par de tópicos mais inovadores, como a música e o mundo sobrenatural. Graficamente, os álbuns poéticos distinguem-se, ainda, pelo número reduzido de páginas, pela im- 
pressão em papel de alta gramagem, pelas capas duras e pelo seu desenho interior e exterior cuidado e original (Silva, 2011, p. 566), designadamente, por exemplo, no que diz respeito às guardas e à própria folha de rosto. Por tudo aquilo que mencionamos, este é um relevante objeto no domínio fundamental da educação literária e, globalmente, na conformação de uma cultura artística.

Uma análise das relações entre comunicação escrita e comunicação visual nos álbuns poéticos, objetivo fundamental do presente estudo, se concretiza em duas seções distintas: uma centrada em um conjunto de álbuns poéticos de autoria portuguesa e outra em outros títulos espanhóis. Essa possibilitará, em última instância, o reconhecimento do grande relevo desse objeto estético no domínio do fomento da leitura, tanto em contextos formais (jardim de infância, escola e bibliotecas, por exemplo) quanto não formais (como é o caso de em família).

\section{ÁLBUNS POÉTICOS EM PORTUGUÊS: AUTORES, TÍTULOS, CARACTERÍSTICAS TEXTUAIS E PARATEXTUAIS E EDITORAS}

Dessa feita, a partir da exemplificação, assente num corpus textual composto por cinco volumes, editados no período de cinco anos, ou seja, entre 2005 e 2010, procuramos identificar as principais singularidades do álbum poético publicado em Portugal. Encetamos, por conseguinte, uma análise de raiz intertextual, procurando, além de registrar as mais relevantes linhas ideotemáticas, bem como os aspectos técnico-expressivos fundamentais, interpretar a conjugação intersemiótica que, entre texto verbal e texto visual, se observa em cada uma das obras selecionadas. Concedemos particular atenção às potencialidades semânticas inerentes às ilustrações, acentuando a sua função na conformação de um sentido poético global.

Em Portugal, muito embora a escrita e a publicação de poesia representem gestos assíduos e interessantes, com uma vasta tradição, a sua apresentação em forma(to) de álbum poético é, ainda, muito escassa ou pontual. Uma certa "timidez" criativa e editorial, um pouco à semelhança do que se constatou nos primórdios do aparecimento no mercado de álbuns narrativos (picturestory books) de autoria portuguesa, começa a ser, porém, desafiada e estimulada. Este fato deve-se ao surgimento de alguns originais exemplares integrados na referida categoria, ou seja, de obras literárias cujo sentido integral e/ou expressividade assenta em uma articulação estética entre as palavras poéticas e a composição ilustrativa, como explicitamos, muitas delas com a chancela de jovens casas editoriais, incluindo a Planeta Tangerina, por exemplo, mas também por outras editoras com catálogos reconhecidos e já com vários anos de atividade, entre elas a Editorial Caminho.

\section{PALAVRA QUE VOA, DE JOÃO PEDRO MÉSSEDER E GÉMEO LUÍS}

É justamente de uma das editoras que acabamos de nos referir, a Editorial Caminho - entre as mais prestigiadas em Portugal - a publicação de Palavra que voa (Caminho, 2005), volume que integra o poema: 
Há palavras / feitas pr'a voar / num céu de Maio. // Leves palavras / ao colo do vento, / construídas / com o papel / colorido / dos teus sonhos. // Tomas uma / e soltas o fio / que a prende / à tua mão. // E a palavra / ganha asas, / eleva-se no ar / com o seu longo / ditongo / voador. // Até encontrar, / no mais alto / de ti mesmo, / um lugar / imenso / para morar. (Mésseder, 2005)

Intitulando-se "Papagaio", o texto poético que ocupa integralmente e em exclusivo a obra Palavra que voa surge reunido no final do volume, possibilitando, assim, uma leitura a posteriori, ou "uma outra leitura", agora já alimentada pela leitura de contato e/ou de profundidade.

Nessa obra, uma espécie de singularidade visual, ou seja, um verso aliado a uma ilustração em cada dupla página, representa o ponto de partida para a pluralidade, na justa medida em que uma certa contenção intencional de palavras, testemunhada na apresentação progressiva de unidades versificatórias soltas (que voam!), induz na busca de múltiplas soluções interpretativas, de caminhos de encontro com o eu poético, que também são, afinal, motivos de reflexão sobre a realização humana/pessoal e o valor ou o contributo das palavras nesse contexto.

Trata-se de um percurso de leitura que muito deve à própria composição visual de Gémeo Luís - GL (1965), uma linguagem profundamente metafórica e simbólica que tem função relevantíssima na expectável (re)construção individual das partes de um texto poético, também eminentemente metafórico, que, apenas no final, como mencionamos, é revelado na íntegra. Nesse espaço conclusivo de reconciliação/religação das palavras poéticas, coincidente com uma página de encerramento, também acompanhada de uma única ilustração, descobre-se o enigma que esconde os vinte e cinco versos de João Pedro Mésseder - JPM (1957), distribuídos pelas treze páginas ímpares, acompanhados, nas páginas pares, pelas ilustrações de GL.

Denegando a disposição gráfica mais comum ao texto poético, em Palavra que voa, um tipografismo "livre" gera efeitos espaciais e óticos inovadores, quer ao nível formal, quer do ponto de vista semântico. A espacialidade alva da página e o lugar mínimo que nesta ocupam as palavras, paulatinamente oferecidas ao olhar do leitor, parecem corporizar a relevância dos "espaços em branco" ou dos "elementos não ditos" no ato de receção estética, indiciando, ainda, um percurso de leitura que motiva a reflexão sobre os sentidos escondidos (ou a sua reconstrução) em cada verso.

Às palavras aliam-se ilustrações de cor única, nascidas da tesoura e do papel minuciosa e criativamente recortado por GL. Esse discurso dual, resultante das palavras e das imagens, parece pautar-se pela metáfora, como avançamos, base retórica e visual da multiplicidade de interpretações possíveis. Nota-se que as figuras humanas, recriadas nas ilustrações, parecem direcionar o olhar no sentido da ascensão ou da verticalidade, como se estivessem de olhos postos no "lugar imenso para morar" a que se refere o sujeito poético. Em contrapartida, a sucessiva disposição ou a localização gráfica dos versos nas páginas do livro orienta-se pela direcionalidade descendente, sugerindo o processo habitual de escrita. Do ponto de vista simbólico, podemos considerar que, enquanto as ilustrações parecem materializar uma ligação ao elemento ar ou ao espaço celeste, corporizados, por exemplo, na representação das nuvens ou na sugestão visual do vento, a componente verbal sugere uma liga- 
ção ao espaço terrestre ou ao real. E desse binômio resulta, assim, uma das linhas temáticas estruturante em Palavra que voa: a oposição real/onírico, eixo que acaba por funcionar como chave interpretativa de "manuseio" possível apenas se o leitor tiver vontade e participar nesse ininterrupto e fértil diálogo intersemiótico entre as ilustrações de GL e a poesia de JPM.

\section{PÊ DE PAI, DE ISABEL MARTINS E BERNARDO CARVALHO}

Editado com uma chancela distinta da obra que acabamos de analisar, Pê de pai é um volume no qual se pressente, desde o importante espaço paratextual que é a sua capa, uma intencionalidade de aproximação ao leitor infantil.

Dos cinco livros selecionados, Pê de pai (Planeta Tangerina, 2006), juntamente com O primeiro gomo da tangerina, que será alvo de análise mais adiante, são os únicos que não oferecem, em uma seção final, o texto verbal reunido ou integral. Em todo o caso - e porque acreditamos que o texto poético apresentado em conjunto poderá possibilitar uma leitura, ou melhor, uma "segunda" leitura semanticamente mais produtiva -, apresentamos, assim, o resultado da recomposição desses vinte e quatro segmentos textuais, distribuídos pelo volume, em pauta:

Pê de pai / Pai casaco / Pai avião / Pai cabide / Pai travão / Pai grua / Pai tractor / Pai sofá / Pai motor / Pai esconderijo / Pai colchão / Pai bóia / Pai esfregão / Pai chocolate / Pai seta / Pai cofre / Pai meta / Pai ambulância / Pai despertador / Pai escadote / Pai doutor / Pai carrossel / Pai cavalinho / Pai túnel / Pai pequenino! (Martins, 2006)

Essa obra, reconhecida em 2006 com uma menção especial atribuída pelo júri do Prêmio Nacional de Ilustração (Direção-Geral do Livro, dos Arquivos e das Bibliotecas - DGLAB/Associação Portuguesa para a Promoção do Livro Infantil e Juvenil - APPLIJ), apresenta uma vertente verbal da autoria de Isabel Martins - IM (1974), visivelmente econômica, profundamente metafórica e visualmente representada em estilo manuscrito/caligráfico - aspecto que, aliás, poderá indiciar a suposta faixa etária do emissor intratextual - , que se articula, de forma eficaz, com as ilustrações de Bernardo Carvalho - BC (1973).

O conjunto pictórico apresenta-se peculiar, pelo jogo contrastivo de tonalidades inesperadas e até pelas próprias formas estilizadas, praticamente reduzidas à representação de aspectos anatômicos fundamentais na expressão de afetos (as mãos, os braços, a boca e os olhos, por exemplo) e, de certa forma, minimalistas. Os segmentos verbais, de índole poética, pela aliteração e pela anáfora, apresentando também uma construção paralelística, baseada na junção da palavra "pai" a uma série de outros nomes pertencentes a universos temáticos tão variados como os transportes (avião, por exemplo), objetos vulgares (sofá ou esfregão, por exemplo) ou doces (chocolate) - note-se que, somente na última sequência, a única pontuada, é utilizado um adjetivo —, distribuem-se progressivamente, página a página, funcionando quase como uma legenda "econômica" das várias ilustrações. Nota-se que estas são fundamentais do ponto de vista da reconstrução/dilucidação 
dos sentidos metafóricos do texto linguístico. É nessa associação sugestiva entre o código linguístico e o código pictórico que se promove uma invulgar relação de cumplicidade autor-texto-leitor, que é, também, um convite para que cada um - pai ou filho - se reconheça/reveja em uma ou outra situação. Refira-se, também, que o registro visual que, em relação às palavras, parece "ambicionar" o sentido literal, se estende às próprias guardas e, mesmo, a outros elementos paratextuais como o código de barras, aqui destituído do seu valor objetivo e/ou técnico e transformado em objeto visual semanticamente fértil.

Concluindo, Pê de pai é uma obra que, pelo cuidado gráfico que ostenta e, muito especialmente, pelo seu inegável sentido estético, merece ser incluída em todas as estantes visitadas tanto por pequenos quanto por grandes leitores.

\section{O MAR, DE LUÍSA DUCLA SOARES E PEDRO SOUSA PEREIRA}

Na mesma linha das obras anteriormente relidas, O mar (Gatafunho, 2008) é composta do seguinte poema:

Este é o mar / onde os barcos viajam, / os peixes moram / os golfinhos saltam, / as baleias lançam repuxos, / as crianças nadam, / os jardins são de coral / e sabem a sal. // Este é o mar / que se esgota em esgoto / se lixa em lixo, / o das marés negras, / das redes de arrasto, / dos rastos de sangue, / dos cemitérios nucleares, / dos muitos azares. // Este é o mar. / Quem é que entende a canção das ondas? (Soares, 2008)

Livro que se distingue pela sobriedade cromática e pela pormenorização da componente ilustrativa e do próprio texto poético, que se estende fragmentariamente pelas suas páginas, $O$ mar testemunha, simultaneamente, a intensidade lírica da poesia de Luísa Ducla Soares - LDS (1939), uma das escritoras portuguesas mais (re)conhecidas da LIJ, bem como o caráter lúdico (refletido nos jogos vocabulares e fonéticos) ao serviço da materialização de um dos seus veios ideotemáticos mais significativos: a crítica.

Tendo como matéria apenas um poema, esse livro é uma espécie de hino ao mar em que cabe também a referência àquilo que de menos "solar" este guarda. O eufórico e o disfórico coexistem, refletindo-se quer na própria estrutura externa (duas oitavas), quer no campo semântico/lexical que domina cada uma delas. $\mathrm{Na}$ verdade, se na primeira estrofe o mar é o espaço dos barcos, dos peixes, dos golfinhos ou dos jardins "de coral", na segunda é o espaço dos esgotos, do lixo, e até dos "cemitérios nucleares", por exemplo. Repara-se que as opções vocabulares da primeira estrofe - na qual se destaca o recurso a formas verbais actanciais ("viajam", "saltam", "nadam" etc.) - sugerem dinamismo e sinalizam o caráter vital do espaço marítimo. O dístico final lança um desafio ao leitor, interpelando-o diretamente e procurando, talvez, despertá-lo (responsabilizá-lo?) para a referida ambivalência e, em particular, para as consequências nefastas de um certo alheamento face a questões ecológicas e de proteção ambiental, linha ideológica, aliás, comum a outras obras da autora (refira-se, apenas a título exemplificativo, à coletânea póetica O planeta azul). 
A componente visual dessa publicação, assinada por Pedro Sousa Pereira PSP (1966), além de traduzir a arquitetura semântica e graficamente dual do texto poético, ganha novos efeitos pelo recurso e pela associação a uma disposição gráfica dos carateres próxima da escrita concreta, visual ou experimental, gerando-se, assim, efeitos espaciais e óticos muito significativos. Efetivamente, as ilustrações, ricas em detalhes que recriam elementos marítimos (barcos, faróis, ondas, peixes e até navegadores), seguem, de modo fiel, a temática central do poema, estendem-se por páginas duplas e parecem orientar a disposição do próprio texto verbal, quebrando a linearidade natural do registro linguístico. A oscilação entre a limpidez dos tons azuis e verdes e a opacidade dos cinzas e marrons deixa, assim, transparecer a duplicidade ideológica que encerra a mensagem do discurso poético.

O Mar distingue-se, portanto, como um especial exemplo das potencialidades estéticas que a associação palavras-imagens, na conformação de um álbum poético, poderá encerrar.

\section{O PRIMEIRO GOMO DA TANGERINA, DE SÉRGIO GODINHO E MADALENA MATOSO}

É da responsabilidade da Planeta Tangerina, editora também de Pê de pai, como vimos, o álbum poético O primeiro gomo da tangerina (2010), obra muito apelativa com texto assinado por Sérgio Godinho - SG (1945), um dos cantautores - letristas e compositores, muitos deles de intervenção - mais importantes da cultura portuguesa, e também autor de algumas obras de potencial receção infanto-juvenil, e ilustração de Madalena Matoso - MM (1974). Trata-se de um livro singular, motivado por um(a) poema/canção. Como se pode ler junto à ficha técnica do volume, O primeiro gomo da tangerina é um poema (e uma música) de SG. A canção foi editada, pela primeira vez, no álbum "Tinta permanente" (1993) e regravada ao vivo nos álbuns "Noites passadas" (1995) e "Nove e meia no Maria Matos" (2008). Como no caso das obras anteriormente analisadas, transcrevemos o poema em causa:

Todos vieram / ver a menina / ao primeiro gomo de tangerina / menina atenta / não experimenta / sem primeiro / saber do cheiro / o sabor dos lábios / gestos sábios // Fruta esquisita / menina aflita / ao primeiro gomo de tangerina / amarga e doce / como se fosse / essa hora / em que chora / e depois dobra o riso / e assim faz seu juízo // Sumo na vida / é o que eu te desejo / um beijo / um beijo // Ah, que se lembre / sempre a menina / do primeiro gomo de tangerina / p'la vida dentro / é esse o centro / da parcela da vitamina / que a faz crescer sempre menina // A terra é grande / é pequenina / do tamanho apenas da tangerina / quem mata e morre / nunca percorre / os caminhos do que há de melhor / nesse sumo / a vida, gomo a gomo // Sumo na vida / é o que eu te desejo / rumo na vida / um beijo / um beijo. (Godinho, 2010)

De uma sensibilidade e musicalidade notáveis, o texto poético de SG convida a uma viagem pelo eu, um regresso à infância ou às primeiras sensações, sempre 
supreendentes, ora doces, ora amargas, mas, de qualquer modo, novas, bem como a sua presença significativa e influência ao longo da vida. A infância, enquanto destino vital de um "eterno retorno", domina todo o poema (como a vida, em geral), mostrando-se a procurar sugerir as suas repercussões nessa "vida gomo a gomo" (Godinho, 2010). Aparentemente simples (e é efetivamente, do ponto de vista lexical), o discurso encerra, no entanto, uma complexidade ideotemática, decorrente, em larga medida, da poetização de tópicos como a diversidade e o bem/ mal, corporizados nos gestos individuais, como se pode ler nos seguintes versos: "A terra é grande / é pequenina / do tamanho apenas da tangerina / quem mata e morra / nunca percorre / os caminhos do que há de melhor / nesse sumo / [...]." (Godinho, 2010). A essa linha isotópica junta-se, ainda, a das relações afetivas, em concreto, até, (possivelmente) do amor, lidas, por exemplo, em "Sumo na vida / é o que eu te desejo / rumo na vida / um beijo / um beijo." (Godinho, 2010)

Esses veios, como facilmente se conclui, são tratados a partir do recurso a estratégias como a metáfora - figura de estilo aqui alicerçante e matricial, na medida em que a "tangerina" poderá ser identificada com a vida ou o mundo (este redondo como o fruto); e os seus "gomos" ou pedaços, com os momentos, as passagens de um percurso, os gestos e os afetos etc. — e a sinestesia — " $[\ldots]$ sem primeiro / saber do cheiro / o sabor dos lábios / gestos sábios [...]" (Godinho, 2010) —, ou a antítese — " [...] amarga e doce / como se fosse / essa hora / em que chora / e depois dobra o riso / [...]”; “[...] A terra é grande / é pequenina / [...].”; “[...] quem mata e morre / [...]" (Godinho, 2010).

A "seriedade" dos eixos semânticos que vimos de enunciar, na sua essência, de índole existencial, parecem, em certa medida, "aligeirar-se" por meio da construção visual de MM. As suas ilustrações apresentam uma multiplicidade de pormenores - espaços/microcenários, elementos da natureza e muitas figuras humanas, por exemplo, diversas na faixa etária, na aparência, nas ocupações etc. - , representados a partir do recurso a uma técnica mista que integra o recorte e a colagem de pedaços de papel e de fotografias e, ainda, o desenho a lápis de cor. Tira-se partido da unidade visual de página dupla, desde logo, nas próprias guardas iniciais, elemento peritextual no qual se sugere movimento, diversão e/ou ludicidade em companhia, e que parece ter continuidade, "fechando-se", depois, nas guardas finais, com a simples representação de um pôr do sol marítimo, em qualquer figura humana. Na verdade, a ilustradora procede a uma espécie de reconfiguração não apenas do real, mas essencialmente do poético, imprimindo-lhe uma carga semântica muito ampla. Palavras, em regra, contidas, registadas em locais periféricos da página, motivam imagens profusas, repletas de detalhes, alguns deles a exigirem um olhar atento.

Ao título $O$ primeiro gomo da tangerina veja-se, por exemplo, o que sucede com o verso/expressão metafórica "A vida gomo a gomo" e com o segmento visual que com ele(a) se articula. Nessa unidade verbo-icônica, em página dupla, o texto, escrito a vermelho, é colocado na página da esquerda (ou par), parecendo ser, depois, visualmente ampliado por meio de uma ilustração que "cresce" até a totalidade das fronteiras da página. É, na verdade, uma imagem criada a partir do recorte e da colagem de pedaços de papel distintos e de partes de fotografias que fixam crianças verdadeiras e, até, uma com uma (aparente) família. A mesma 
menina que protagoniza a poesia de SG sorri e estende as mãos na direção de várias borboletas esvoaçantes na composição visual de MM. O efeito expressivo é singular e semântica/simbolicamente poder-se-á, até, pressentir aquilo que é, no essencial, uma "vida gomo a gomo": os pés na terra, com os olhos e o coração no céu, ou melhor, no sonho, enquanto gesto vital.

\section{A CHARADA DA BICHARADA, DE ALICE VIEIRA E MADALENA MATOSO}

Registramos, ainda, um comentário acerca de uma outra obra, igualmente ilustrada por MM, mas com algo em sua configuração que a distingue das obras analisadas anteriormente, muito embora deva, na nossa opinião, ser igualmente integrada na categoria do álbum poético. Trata-se, com efeito, de um dos mais originais volumes de poesia para a infância, intitulado $A$ charada da bicharada, (Texto, 2008), de Alice Vieira - AV (1943), um dos nomes incontornáveis da LIJ portuguesa. A sua composição visual e, naturalmente, o seu grafismo, cuidado e esteticamente irrepreensível, valeram à sua ilustradora, em 2008, o Prêmio Nacional de Ilustração.

As composições poéticas que integram essa obra, 14 no total, centram-se em animais de espécies distintas. Do gato ao rato, passando pelo macaco e pela zebra, até a cobra e a borboleta, a presença animal pontua as palavras de AV, escritas com simplicidade, mas, em certos casos, com lirismo significativo. Recorrendo a opções enunciativas diversas - de modo assíduo na primeira pessoa, em discurso direto (como no poema iniciado com o verso "Algumas pessoas gostam de mim" e dedicado à(ao) pomba(o)), ou na terceira pessoa (como em "Felino. As garras prontas", centrado no gato), por exemplo - AV não deixa de imprimir, também assiduamente, um fino tom humorístico à sua escrita poética (à semelhança do que sucede nos seus reconhecidíssimos textos narrativos de maior ou menor extensão). Releiam-se o segmento "Eu não sei se ele é rei, como promete: / mas lá que mete respeitinho... mete!”(Vieira, 2008, p. 7), referindo-se ao leão, bem como o poema dedicado ao rato:

Certos bichos... enfim, / - sem mau intuito... - / quer-me parecer a mim / que simpáticos, simpáticos... / não serão lá muito! // Gostar desses bichinhos queria eu, / mas não consigo. // (Só abro uma excepção: / para um tal chamado Mickey, / meu amigo.) (Vieira, 2008, p. 15)

De extensão relativamente breve, os poemas acabam por funcionar - como, aliás, anuncia o próprio título da publicação - como adivinhas e/ou charadas, e as ilustrações, absolutamente imprescindíveis para a conformação do sentido integral dos textos, reforçam e potenciam, também, o seu caráter enigmático. $\mathrm{O}$ próprio caráter lúdico da publicação é sustentado, de forma determinante, pelo registro visual, muito profuso e cromaticamente apelativo, uma composição sempre em dupla página que oferece pistas de descodificação dos poemas. Em todas as imagens da obra, incluindo as das próprias guardas iniciais e finais - espaços paratextuais com construção pictórica diferenciada -, esconde-se a figura de um animal, que 
protagoniza, sucessivamente, portanto - como mencionamos - , um texto poético sem título e que apela à descoberta dessa espécie de "solução", seguindo um caminho similar ao das charadas. O registro icônico, distinguindo-se pela sutileza e pelo enigma, convoca um olhar insistente e curioso, que fica imediatamente preso às cores muito vivas, contrastivas e fortes que compõem uma paleta muito atrativa e livre - veja-se, por exemplo, a opção pelo uso do preto em vários segmentos visuais. A título exemplificativo, observa-se o seguinte poema:

Gosto é correr, correr, correr! / Sou uma paz de alma e disso tenho fama. / Mas quem me quiser zangar é só dizer / que sou um boi de pijama... // Vivo longe, nas planícies cruas, / mas tenho irmãs, aqui por esta banda, / que gostam de se deitar nas ruas, / só para dar protecção a quem lá anda... (Vieira, 2008, p. 24)

A "leitura de contato" permite sinalizar a presença de pistas de descodificação que se prendem quer com a aparência física do animal poetizado (no caso supracitado, é do conhecimento geral a identidade do animal que anda de pijama), por exemplo, quer com o seu habitat. Os dois últimos versos, porém, evidenciam certo hermetismo, reclamando um olhar perspicaz sobre a profusa ilustração que acompanha o texto. Na verdade, é no "quadro" visual, recriando um cenário urbano, que se descobrem várias faixas de pedestres e, em particular, uma na qual se esconde mesmo uma zebra. Poetisa e ilustradora jogam com a metaforização do senso comum que identifica as faixas com zebras.

A poesia de $\mathrm{AV}$ e as ilustrações de MM, dois discursos eficazes e inevitavelmente associados ou complementares, reclamam uma leitura dialogante, muito estimulante, pelo mistério e pela surpresa que encerram, e resultam em uma arquitetura esquemática, segura e muito do agrado do leitor infantil (mas não apenas, naturalmente).

\section{ÁLBUNS POÉTICOS EM ESPANHOL: AUTORES, TÍTULOS, CARACTERÍSTICAS TEXTUAIS E PARATEXTUAIS E EDITORAS}

Na Espanha, sobretudo a partir de 2005, podemos assinalar a publicação de álbuns poéticos por editoras como Bornova, Edelvives, Kalandraka Ediciones, República Kukudrulu, SM e Thule.

O objetivo do que a seguir se apresenta reside em examinar seis álbuns poéticos em espanhol, tendo em conta o potencial leitor ao qual se dirigem, as temáticas que aí se poetizam, bem como o papel de que se reveste a ilustração para potenciar a compreensão dos versos que aí se inscrevem.

\section{SER Y PARECER, DE J. LUJÁN}

Ser y parecer (2005) é um álbum poético de 32 páginas, publicado pela Editorial SM/México. A partir da congregação de dois versos livres na maioria das páginas ilustradas, o autor argentino Jorge Luján expõe o desejo especial de uma menina: que alguém decida empreender a vasta viagem que conduz ao seu ser 
mais íntimo. Por sua vez, Isol, uma jovem ilustradora argentina galardoada com o prestigioso prêmio de LIJ Astrid Lindgren (2013), apresenta ao leitor um conjunto de ilustrações para que esse possa conhecer o ser profundo que possui cada pessoa. Descobrimos, então, o corpo humano de uma maneira diferente da tradicional, já que o aspecto exterior, por vezes, pode enganar-nos.

Na capa do álbum, observa-se a protagonista do texto segurando um guarda-chuva que possui a forma de seu rosto. Este encontra-se voltado para o céu em direção a umas gotas de água desenhadas em tons de azul-claro, aparentemente metaforizando as ideias e impressões que as pessoas têm umas das outras. Os dois primeiros versos do álbum em análise, "Soy lo más distinta de mí / que te puedes imaginar" (Luján, 2005, p. 9), convidam o leitor a não ater-se apenas às aparências que cada indivíduo possui sobre si mesmo. Daí o título dessa obra. A imagem da protagonista atirando uma pedra ao mar e o reflexo difuso de uma figura humana poderão ser lidos como uma metáfora visual da percepção, muitas vezes parcial, que detemos do ser humano. Além disso, como sugere a imagem em causa, para conhecer o interior de uma pessoa, primeiro é necessário começar por fora: nesse caso, pela silhueta do corpo humano. As páginas seguintes ( 9 a 18) já nos revelam o interior profundo da pessoa, em concreto, algumas partes e órgãos do corpo humano: a da frente, em que se alojam as ideias que navegam pela mente, como peixes num aquário; as orelhas, que, apesar de terem a aparência externa de uma clave de Fá, não sabem, na realidade, distinguir duas notas musicais, como o Dó e o Lá; o nariz, pequeno e perdido na cara, mas que é capaz de cheirar à distância verso ilustrado ao jeito metafórico com a imagem do mundo como uma bola com biscoitos situados no outro lado do planeta; a boca fechada e, ao mesmo tempo, aberta, para introduzir objetos em ocasião menos desejada; e os olhos, que, mesmo ajudados por lentes, não veem mais além do que o nariz, ainda que sejam capazes de perceber o sentir das pessoas e o seu estado de espírito. Esta última ideia reflete-se nas ilustrações de pequenos seres diminutos que correm à volta do contorno dos olhos da protagonista.

A partir da página 21, ela aspira tornar-se mais acessível ao leitor. Inclina o seu corpo, fazendo-o girar sobre o seu pé: "Si tú quisieras conocerme / yo giraría sobre un pie". Uma vez inclinada, a heroína adverte que "pero te esperaría un largo viaje / desde mi apariencia hasta mi ser", uma viagem que continua da página 23 a 32 sem versos, mas com imagens sugestivas que possibilitam ao leitor entrar no corpo da menina, encetando uma viagem até os seus olhos (Luján, 2005, p. 28-29). Enquanto o leitor se situa no olho direito da protagonista, esta olha-o sorridente com o próprio olho esquerdo.

Esse álbum poético, de receção dual, é, acima de tudo, um convite a julgar cada pessoa, e a julgar-se, não pela visão aparente que se tem de cada um, mas, e sobretudo, pela essência que o define como um ser único e individual.

\section{POEMAS A LA LUNA}

Poemas a la luna (2009) é um álbum poético ilustrado por Gianni De Conno (Prêmio Communication Arts Award of Excellence em 1998, 2000, 2001, 2007,2008 e 
2009 e Medalla de Oro de la Sociedad de Ilustradores de Nueva York em 2008 e 2010) e publicado pela editora Edelvives. É composto por textos poéticos na língua original em que foram escritos (inglês, alemão, grego, italiano, japonês e chinês), de diferentes autores (Christina Rossetti, Emily Dickinson, Johann Wolfgang Goethe, George Gordon Byron, Percy Shelley, Safo, William Shakespeare, Giacomo Leopardi, Wang Wei, Yosa Buso, Matsuo Basho e Walt Whitman). As composições são acompanhadas de uma versão/tradução em castelhano. Encontramos como único autor espanhol, e nas páginas centrais deste álbum, o poeta Federico García Lorca. O que primeiramente chama a atenção nessa obra é a sua considerável/extensa dimensão, bem como a sugestiva ilustração da capa, espaço paratextual no qual observamos uma personagem em tamanho mediano, vestida de vermelho, a abrir uma caixa azul que contém o firmamento noturno e a própria lua. Nesse firmamento, destaca-se a lua minguante, numa cor branca, intensa e luminosa. É, aliás, a mesma que se vê nas guardas e que ilumina cada uma das páginas desse texto de tonalidades frias e no qual se destacam diversas silhuetas femininas, frequentemente disseminadas, que parecem constituir a encarnação da lua numa figura humana.

Nesse álbum, a lua é frequentemente interrogada por cada um dos poetas selecionados, dando azo a textos inundados de lirismo. $\mathrm{O}$ primeiro poema que integra a obra (Rossetti, 2009, p. 5-6) é de autoria de Christina Georgina Rossetti (1830-1894). Nele, interroga-se indiretamente a lua (“Está la luna cansada?"), e descreve-se a sua beleza branca, antes da noite escura ("Antes de que la noche se torne oscura / la luna muestra su blancura"), para, depois, desaparecer, logo que chega o amanhecer (" $y$, luego, antes del amanecer / decide desaparecer"). O poeta contempla a lua com a atitude de um espectador ativo, gesto refletido na ilustração de uma silhueta feminina bem definida, em cima de um grande cavalo, que permite ao seu cavaleiro, aparente metáfora da própria Rossetti, tocar a lua no meio da noite estrelada. A ilustração, em tom verde/azul-escuro, situa o leitor em um ambiente frio e decididamente noturno. O poema seguinte (Dickinson, 2009, p. 7-8), apenas com quatro versos, é também de uma poetisa em língua inglesa: Emily Dickinson (1830-1886). Neles, o leitor descobre a fragilidade da lua ("que, como la luna, una noche túrbida / se ve arrastrada por las mareas"). Essa fragilidade encontra-se ilustrada em quatro imagens da lua que descrevem o processo que vai desde a lua nova até a minguante. Debaixo de cada lua aparece a figura de uma mulher que, pouco a pouco, vai ficando desfocada, à medida que a lua vai reduzindo o seu tamanho e a sua luz.

O terceiro poema (Goethe, 2009, p. 8-9) é de autoria de J. W. Goethe (17491832). Os oito versos dessa composição poética representam um pedido que o poeta dirige à lua para que esta desperte na noite quem tem necessidade da sua luz: "despierta en las grutas tenebrosas / a las tristes almas dolorosas / y, conmigo, a las nocturnas aves". A lua é, para o eu lírico, "hermana de la luz primera" " "imagen de la ternura en duelo", uma figura ilustrada por De Conno com uma grande cara branca e amável, contrastando com uma figura masculina, dura e negra, a cavalo. O quarto poema deste álbum ilustrado, de autoria do poeta inglês Lord Byron (1788-1824) (Byron, 2009, p. 10-11), evidencia-se como uma exortação dirigida ao leitor de seus versos: "no volveremos a vagar / a la luz de la luna", ainda que esta "conserve su claridad". $\mathrm{O}$ verbo vagar parece encerrar, aqui, a acepção de amar. Daí que o sujeito poético, 
na sua estrofe central, exclame, em jeito de sentença: "pues, asi como la espada perdura en la vaina, / el alma acaba con el pecho / y el corazón se detiene / también el amor debe descansar". Esse descanso surge ilustrado por De Conno com um desenho em tons frios de uma mulher que corre uma cortina, metáfora do dia que chega, para não deixar passar a luz da lua.

O poema seguinte (Shelley, 2009, p. 12-13) é assinado por Percy Bysshe Shelley (1792-1822). Trata-se do anseio do poeta cuja alma se encontra fatigada de subir ao céu ("Acaso te demuda la fatiga / de tanto ascender al cielo"), de encontrar e contemplar a lua que não se distingue entre tantos corpos celestes: "vagando sin compañia / entre las estrellas desiguales / y sin rumbo fijo". Essa busca é semelhante à que realiza um olho ("que no encuentra objeto digno / [de su perseverancia]?") que surge ilustrado a partir da figura de uma esfera negra, sustentada pela mão de uma mulher, que contempla a lua minguante, no denso firmamento estrelado.

O texto lírico de Safo (Safo, 2009, p. 13-14), poetisa grega que viveu entre os séculos VII e VI a.C., afigura-se como um aviso de que "se ha puesto la luna / y las Pléyades", versos que De Conno ilustra com a imagem de três janelas de arco tracejado. Por meio dessas, observa-se o processo gradual da lua até o seu esplendor, junto à constelação de estrelas das Plêiades, no firmamento escuro. Assim que a noite alcança a sua plenitude, a poetisa sente-se golpeada por Eros ("Eros me ha golpeado / en el vientre") até ao ponto de a sacudir como "fiera dulce y a la vez amarga, invencible". A imagem que recria essa antítese, que não deixa de encerrar uma leve essência paradoxal, consiste na ilustração de um lobo negro manso que é tocado e acariciado por uma figura feminina. $\mathrm{O}$ poema finaliza com a expressão da nostalgia que domina o poeta em relação ao amor e, ainda, do desejo de poder tocá-lo: "Siento añoranza y anbelo de tocar".

Após essa composição poética, encontramos um diálogo entre Romeu e Julieta (Shakespeare, 2009, p. 15-16), extraído da célebre obra homônima de W. Shakespeare (1554-1616). A ilustração que se junta a esse diálogo é especialmente apelativa: dois rostos serenos e redondos em tom ocre, unidos por uma lua decrescente com os mesmos olhos que esses rostos. A lua surge recriada em esverdeado e destaca-se sobre o tom mais suave evidenciado pelos rostos humanos. O diálogo entre Romeu e Julieta coincide com o juramento do amante à sua amada, assegurando-lhe a fidelidade do seu amor: "Señora, juro en nombre de la luna sagrada I que de plata baña las copas de estos frutales [...]”. Julieta suplica-lhe que não jure em nome da lua, já que esta "cada mes cambia su esfera" e teme que a sua promessa de fidelidade seja também mutável: "no sea que vuestro amor resulte tan cambiante". Pede-lhe, em contrapartida, que jure em nome próprio ("No juréis; / y, si lo bacéis, que sea en vuestro gentil nombre") e, sendo assim, acreditará nessa promessa de amor: " $y$ en ese caso os creere". A ilustração de dois rostos simétricos unidos pela lua facilita a compreensão, e até a própria imaginação, de como se concretiza esse diálogo entre as duas personagens citadas.

Os versos de Federico García Lorca (1898-1936), que integram o conhecido Romancero Gitano (1928) e que encontramos nas páginas 17 e 18 desse álbum poético, apresentam-nos a lua cigana, companheira da morte: "cuando sale la luna/ 
se pierden las campanas / y aparecen las sendas / impenetrables". E é assim quando "el corazón/se siente solo en el infinito". Esse pedido surge pictoricamente representado por meio de um coração que, com a forma de uma ilha, encontra o seu lugar na linha do horizonte de um mar de tons verde-escuros. $\mathrm{O}$ coração, metade vermelho intenso e metade negro, é contemplado por um rosto feminino grande cuja cabeleira é o céu estrelado com uma minúscula lua minguante.

O poema de Giacomo Leopardi (1798-1837) (Leopardi, 2009, p. 19-20) corresponde a uma interrogação dirigida à lua silenciosa (" $\dot{¿} Q u e ́$ haces luna, en el cielo? ¿Qué haces / silenciosa luna?") e eterna cujo ciclo se apresenta semelhante ao de um pastor que, de manhã, sai com o seu rebanho e, à noite, descansa: "Similar es tu vida / a la del pastor. Sale con los albores del dia; guia a la grey por el campo y ve / fuentes, hierbas y rebaños; cae la noche y exhausto / su gran deseo es descansar". A paisagem lunar de todo esse poema surge ilustrada com um céu pouco estrelado e de tonalidades semiescuras que não se distingue do mar no qual vagueiam cinco figuras de tubarões escuros e brancos. Estes animais parecem seguir um veleiro cujo mastro central sustenta uma vela de grande dimensão e que tem estampada uma difusa lua minguante.

Wang Wei (699-759) apresenta, nos seus versos (Wei, 2009, p. 21-22), a lua outonal que chega com algum atraso: "Acaba de llover sobre el monte vacio; / el otoño llega este año con retraso". A ilustração que acompanha esse poema não pode ser mais eloquente: uma redonda e grande lua em tons alaranjados que se distingue num céu escuro. A essa mesma lua outonal alude, igualmente, Matsuo Basho (1644-1694): "luna de otoño / irrumpe ante mi puerta / la pleamar". Depois da lua de outono, vem a de inverno, com a mudança da estação a que se refere o japonês Yosa Buson (1716-1784): "primera nieva: / acariciando el suelo / la luna de bambü". Esses dois últimos poemas (Buson, 2009, p. 23-24), patentes na mesma página, dada a sua brevidade - traço que permite filiá-los no universo do haiku -, são ilustrados com um mar alto no qual se distingue o barco de um pescador que lança as redes ao nascer do dia. Essa maré alta encontra-se presidida por uma grande lua adormecida, de tons claros.

Walt Whitman (1819-1892) exorta a lua para que desça o seu olhar do céu ("Baja tu mirada, luna hermosa, e ilumina esta escena") e contemple "los muertos tendidos de espaldas con los rostros extendidos". O poeta, no final do texto, pede à lua que derrame o seu resplendor sobre esses cadáveres: "y sobre los muertos tendidos de espaldas con los brazos extendidos; derrama, luna sagrada, tu aureola sagrada." Na ilustração, salienta-se o contraste entre o tom escuro do firmamento, no qual resplandece a lua, e os tons claros e vivos da terra, da qual surgem três braços e duas mãos que rodeiam um crânio humano.

Poemas a la luna, expressivamente ilustrado, é um "espaço" interartístico no qual não apenas o leitor infantil, mas também, sobretudo, o juvenil e o adulto, podem saborear cada imagem. Trata-se de um grande livro tanto no conteúdo, nascido do texto e da imagem, quanto na sua própria aparência gráfica, que, efetivamente, se encontra em consonância com as novas tendências da LIJ que tem sido publicada na Espanha desde o início do ano 2000. 


\section{LA MEDIA NARANJA, DE ELENA FERRÁNDIZ RUEDA}

La media naranja (2009), de Elena Ferrándiz Rueda, é mais um álbum poético, publicado pela Editora Thule, que merece a nossa atenção neste estudo. $\mathrm{O}$ formato do livro - meia laranja - e o seu conteúdo apresentam-se em paralelo: a história da meia laranja Tina que vai em busca da sua outra metade, Clemen, na tentativa de que essa a complemente para poder tirar-lhe todo o sumo da vida: "Más sola que la una, / para sentirse entera / sintió que le faltaba / su alma gemela" (Rueda, 2009, p. 7). Esse processo de busca, ilustrado com a imagem de Tina olhando por meio de um óculo (Rueda, 2009, p. 8-9), resulta em uma grande quantidade de metades de laranjas ("La agenda entera llenó/ de cantidad de mitades") (Rueda, 2009, p. 10), apesar de todas evidenciarem um "senão": "Unos resultaron ácidos / otros muy empalagosos / otros duros de pelar / y los que solo eran hueso, / le resultaron muy sosos"(Rueda, 2009, p. 10). A ilustração da acidez consiste em uma personagem masculina com cara de meio limão; a do enjoativo é outra figura masculina de meia cara e que, nas suas mãos, segura uma nuvem de algodão de açúcar; e a da dureza é uma terceira personagem masculina de meia cara com o corpo coberto por uma armadura.

Tina prossegue a busca do seu amor até que "las lágrimas llorando/se llevaron el color" (Rueda, 2009, p.11). E, quando menos esperava, "lo divisó en una rama / del mayor árbol del parque / estrellitas en la frente / parecía que tenía / al decir su nombre: ¿Clemen!' (Rueda, 2009, p. 12). Surge, então, o amor entre essas duas personagens, um amor que não será nada fácil: "Aunque encajaban del todo, / Tina no hallaba el modo / de separarlo del árbol / y llevárselo al otro lado" (Rueda, 2009, p. 17). Inclusive, Clemen adverte Tina que "no estaba seguro, / que aunque la quería / no estaba maduro" (Rueda, 2009, p. 18). Uma grande ilustração de meia cara dessa personagem masculina revela-nos essa insegurança. Tina, porém, persiste em conseguir esse amor - " $Y$ llovian palabras, / y llovian besos, / y ella lo esperaba / calándose hasta los huesos" (Rueda, 2009 , p. 20) - atitude que surpreende Clemen, representado visualmente no meio de um aguaceiro que cai sobre a figura de Tina. Esta, a partir da terra, contempla a sua meia laranja que pende de uns ramos de uma árvore.

No final, porém, acontece o que tinha de acontecer: "cuando menos lo esperaba, lél se cayó de la rama” (Rueda, 2009, p. 21). Tina, que é recriada visualmente vestida com um apelativo traje branco, segura na sua mão uma maleta, também branca, na qual guarda Clemen: "Ella lo fue a recoger / con una maleta blanca / y se lo llevó a su casa” (Rueda, 2009, p. 21). O final do álbum em análise é totalmente imprevisível: Tina vai à cozinha, toma Clemen nas suas mãos, " $y$ sin que le diera tiempo, / mientras él le daba un beso, / ella fue ... y lo exprimiö" (Rueda, 2009, p. 23). No "quadro" ilustrativo dessa cena, predomina um grande espremedor manual, e é com ele que a coprotagonista feminina tira todo o sumo da meia laranja de Clemen, que tende os seus lábios para os de Tina.

La media naranja é uma obra na qual os diversos poemas e a sua ilustração se complementam na perfeição, oferecendo ao leitor a possibilidade de conhecer a atividade e a essência de ambas as personagens. 


\section{LOS MEAGRADA, DE ÁLVARO FIERRO}

Los Meagrada (2011), escrito por Álvaro Fierro (Prémio Rafael Morales de Poesía em 1993 e, em 1999, alcançou um dos Accésits del Adonáis) e Gracia Iglesias (III Prémio Gloria Fuertes de Poesía Joven em 2001, XIX Prémio Nacional de Poesía Miguel Hernández em 2004 e VII Prémio Luna de Aire em 2009), com ilustrações de Susana Rosique (Prémio Concurso de Navidad 2010 da rede professional do mundo Editorial Ediciona), é um álbum poético publicado pela Bornova. À primeira vista, parece uma forma narrativa breve, mas quando se lê o texto detalhadamente, observamos que é composto por alguns micropoemas de dois, três e quatro versos que evidenciam uma unidade temática. $\mathrm{O}$ título dá nome aos seus protagonistas: os meagrada são extraterrestres que chegam ao planeta Terra e se maravilham com as riquezas e paisagens que o planeta possui. É um texto dirigido, fundamentalmente, ao público infantil para que descubra as maravilhas que o rodeia.

Esses extraterrestres, como se observa na capa, procedem de outros planetas e estrelas e, a partir de uma nave espacial, saltam de paraquedas para "aterrizar en un planeta / lleno de maravillas" (Fierro, 2011, p. 7). Além disso, a um deles agrada "que a este / planeta tan azul / lo llamen Tierra” (Fierro, 2011, p. 7). A ilustração na qual essa aterragem surge recriada não pode ser mais explícita: dois pequenos seres, de nariz muito grande para perceber os cheiros da Terra, olham com espanto o cenário natural azulado que, para eles, é novo. A descoberta da Terra é progressiva: conhecem as linhas do comboio que parecem "escaleras que van al cielo" (Fierro, 2011, p. 9); os campos de cultivo que, para eles, são "las costuras de la tierra", verso que é ilustrado com terrenos em forma de polígonos bem diferenciados pelos frutos e pelas flores, onde se encontram plantados; as galinhas (Fierro, 2011, p. 11); as gotas de chuva (Fierro, 2011, p. 15); os semáforos verdes da cidade (Fierro, 2011, p. 23); as aranhas (Fierro, 2011, p. 27); e a lua que nos sorri quando vamos dormir (Fierro,2011, p.33).

O que se destaca, porém, nesse álbum poético, são as várias metáforas visuais nas quais os elementos do binômio palavra-ilustração se sustentam mutuamente: "me agrada que el viento / se haga un lío con tus cabellos" (Fierro, 2011, p. 13), versos que são desenhados com um dos extraterrestres aprisionado pelos compridos cabelos de uma sereia de grandes dimensões; "me agrada que un avión / le baje la cremallera al cielo" (Fierro, 2011, p. 14), a figura de um pequeno avião verde e vermelho que deixa atrás de si uma estrela e cuja passagem pelo céu compõe uma semicircunferência;" $m e$ agrada esconder el reloj" (Fierro, 2011, p. 16), a representação visual de um grande pelicano que parece que está engolindo um despertador; e "me agrada imaginar / que las personas que son notas musicales" (Fierro, 2011, p. 17) e a ilustração de uma pauta na qual minúsculas figuras humanas se seguram penduradas em cada uma das partes desse esquema musical. Outras metáforas são, todavia, mais visuais, porque a palavra em si já é uma metáfora que é necessário desenhar duplamente: "me agrada que a los árboles/le nazcan mariposas en primavera” (Fierro, 2011, p. 19). Essas borboletas são as folhas que crescem nas árvores na primavera e que se lançam a voar, à medida que o vento as arranca dos ramos. Esse álbum poético finaliza com um dístico que convida o leitor a deixar-se levar e a vislumbrar um mundo maravilhoso: "me agrada que la noche / vista el cielo de fiesta” (Fierro, 2011, p. 34). A ilustração desses versos 
é dominada por uma figura feminina de olhos fechados, com um vestido de festa brilhante, formado por cada uma das estrelas que cobrem o firmamento. Depois de finalizarem o seu percurso pelo planeta Terra, os meagrada dirigem-se para as suas naves (Fierro, 2011, p. 35-36) para regressarem aos seus lugares espaciais de origem. $\mathrm{Na}$ contracapa desse álbum poético, encontramos dois versos que são um convite a saborear, como los meagrada, as maravilhas da Terra: "Me agrada que tengas este libro entre tus manos / y que descubras con él un mundo de maravillas".

Los Meagrada é um texto poético simples, mas profundo e dotado de uma grande plasticidade visual. As suas imagens são sugestivas e expressivas, convidando para um mergulho no mundo da poesia.

\section{ALMANAQUE MUSICAL, DE ANTONIO RUBIO}

Almanaque musical (2012) destaca-se como um livro de poesia de A. Rubio, ilustrado por David Pintor (Prêmio especial no Festival Nami Island International Illustration Concours de 2013 e Prêmio Communication Arts na seção de ilustração em 2014, entre outras muitas distinções) e publicado pela Editora Kalandraka, em formato cartonado. É formado por 12 poemas, um para cada mês do ano, e a música clássica é a protagonista. A pauta, o tempo, o ritmo e as notas musicais formam um conjunto perfeito e harmonioso. Em cada um desses poemas, observamos, nas suas ilustrações, uma mesma orquestra de músicos, humanos e animais, vestidos à risca, que tocam instrumentos em diversas condições temporais/metereológicas, segundo a época do ano na qual se encontram. Assim, por exemplo, o poema "Enero" encontra-se ilustrado com uma paisagem branca na qual a neve cobre os campos e os telhados do espaço em que os músicos tocam. Em contrapartida, no poema "Abril", a orquestra de músicos interpreta uma melodia embaixo de um guarda-chuva negro que os abriga da chuva. As ilustrações ajudam a definir as mudanças de estação com variações de cor e de paisagens. Em cada uma das 12 composições, o poeta escolhe a rima soante/assonância que lhes concede uma sonoridade mais marcada. Esse padrão, próprio da lírica popular, permite ao leitor do texto estabelecer nexos entre a palavra escrita e a imagem que a procura recriar. A obra complementa-se com uma relação escrita de peças de Vivaldi, Bach, Mozart, Beethoven, Mendelssohn, Brahms, Chaikovski, Sibelius, Prokofiev, Alban Berg, Béla Bártok, Boccherini, Haydn e Dvorak, um repertório ideal para ir escutando enquanto se lê os poemas e se disfruta de cada uma das ilustrações.

No poema Enero (Rubio, 2012,p. 5-6), a orquestra interpreta Preludio de nieve para violinos e violas e para violoncelo e contrabaixo. Os dois primeros instrumentos espalham as suas notas no tapete macio de neve e os dois últimos, de sonoridade mais aguda, adornam as brancas copas das árvores. Em Febrero (Rubio, 2012, p.78), estabelece-se um paralelismo entre as notas musicais e os flocos de neve que espreitam no mês: "Caen como arpegios / blancas notas lentas / de algún pentagrama/ oculto en la niebla”. Os músicos interpretam as suas melodias, a partir do interior de uma casa de três pisos, debruçados em seis janelas pelas quais vêem cair os flocos da neve. Marzo (Rubio, 2012, p. 9-10) é o mês do ar ventoso "que inicia un crescendo". A intensidade do som musical aumenta e o vento também ("a todos los músicos / 
le roba el sombrero"). No poema Abril (Rubio, 2012, p. 11-12), os músicos cantam quatro figuras musicais da pauta, "negras y corcheas/semifusas, blancas", debaixo de um amplo guarda-chuva sobre o qual caem "gotas agudas / pizzicato de agua", ou seja, as gotas beliscam o topo do guarda-chuva como os músicos beliscam as cordas de um instrumento musical. Em Mayo (Rubio, 2012, p. 13-14), eles fazem crescer estantes de música, coincidindo com um mês em que tudo volta a brotar: "Hace crecer mayo/ atriles de hojas / sobre la floresta / de madera airosa". Há mesmo espaço nesse poema para metáforas surrealistas: "La música es verde", ou seja, é fonte de vida como as folhas verdes e frescas que cobrem os ramos das árvores. Em Junio (Rubio, 2012, p. 15-16), os músicos vão de férias numa limusine vermelha: "Aparca instrumentos / en junio la orquesta / y en una gran limusina / los músicos vuelan”. Os seus fatos são azuis com riscos e, no fundo da ilustração, observa-se um mar azul iluminado por um diminuto, mas quente, sol. O verão chegou e "[...] estalla / con aires de fiesta". Julio(Rubio, 2012, p. 16-17): este é um poema com metáforas e adjetivações ousadas - "La clave de sol / es una barcaza / con el remo insomne / sobre el agua clara". É um mês favorável para a interpretação de peças com ritmo "alegro non presto" sobre um barco que flutua no mar azul. Em Agosto (Rubio, 2012, p. 18-19), eles disfrutam da água estival, flutuando sobre a caixa harmônica dos seus instrumentos reparados pelos luthiers: "Los viejos luthiers / hacen barcos nuevos / con la caja armónica / de los instrumentos". É o mês destinado à interpretação da Tocata de estio. Septiembre (Rubio, 2012, p. 20-21) é o mês da colheita de frutas. Uma ilustração quente na qual se destacam os tons vermelhos e verdes-escuros apresenta-nos a orquestra de músicos à volta de uma mesa, desfrutar de alguns manjares, enquanto interpretam melodias alegres: "Septiembre de frutas / en la mesa larga. / [...] / acordes de plátano y ciruelas mágicas". No período os músicos interpretam uma Sinfonía de cuerda afrutada. Em Octubre (Rubio, 2012, p.22-23), regressam os ventos que fazem desse mês uma Vals de hojas otoñales. A ilustração do poema recria a orquestra, voando pelo firmamento de uma cidade outonal, apoiada pelas folhas que vão caindo das árvores. Destaque-se a personificação do vento que "compone cantares / y orquestas aéreas / que interpretan bailes". Noviembre (Rubio, 2012, p. 24-25) é o mês de resguardar-se em um lugar e de disfrutar do cálido fogo: "Es noviembre hogar / de cálido fuego". Ao abrigo do fogo, como nos mostra a ilustração do poema, os músicos "[...] afinan a pulso / cuerdas e instrumentos”. Por último, Diciembre (Rubio, 2012, p. 26-27). O ano termina e, com ele, coincide o regresso dos músicos ao cenário para interpretar o Alegre concierto de paz navideño. A ilustração do poema corresponde à encenação da orquestra sobre um cenário de tonalidades avermelhadas.

Almanaque musical é um álbum poético ilustrado no qual o leitor pode seguir, ao longo dos 12 meses, uma mesma orquestra de músicos que vão assistindo às mudanças trazidas por cada mês e estação. As expressivas ilustrações são um elemento necessário para a leitura de um livro como esse, que harmoniza palavra, imagem e música.

\section{A LO BESTIA, DE MAR BENEGAS}

A lo bestia (2011) é um álbum poético de M. Benegas, publicado em papel cartonado pela Editora República de Kukudrulu, com ilustrações de Raul Nieto 
Guridi (vencedor do concurso Mascota Ilustratour 2011). Trata-se de um poemário com muito ritmo e musicalidade no qual diferentes animais interagem com o leitor. Esse jogo poético concebe-se como um convite para que o potencial receptor também se converta em um animal, além dos que aí já aparecem.

$A$ lo bestia é um animalário composto por um conjunto de poemas escritos em chave de humor e nonsense. É composto por três partes. Na primera, "Como las sardinas", encontramos as pessoas mais próximas da criança. Dentre todas elas, destacam-se as seguintes: La madre cotorra (Benegas, 2011, p. 9-10), ilustrada com a figura de uma galinha que, no peito, leva amarrado um avental, "que habla sin prisa y sin causa" e que "si encuentra a un amiga en el horno / ya sé que me toca platón"; Mi hermano cachorro (Benegas, 2011, p. 11), que é ";Un canguro llorón!, / un enano sin dientes, / un pañal con sorpresa / siempre oliendo a serpientes" (o desenho da figura humana na qual se destaca a fralda não poderia ser mais ilustrativo); El padre jabali (Benegas, 2011, p. 12), que está "tumbado en el sofá / resopla como un búfalo / ¡no deja de roncar!' (a ilustração de um pequeno javali, dormindo num sofá com as mãos sobre a barriga inchada, dá-nos essa ideia de sonoridade que nos transmitem os versos do poema); Abuelo tortuga (Benegas, 2011, p. 14), desenhado com uma grande carapaça que quase o esmaga, já que "camina muy despacio: / no quería hacerse daño"; e os Hermanos camaleón (Benegas, 2011, p. 17), que "según como tenga el día te destruye la alegría". Esses estados de humor são, pois, mutáveis (como mutável é a pele do camaleão e assim o ilustra Guridi) e próprios de dois irmãos adolescentes "que vacian el armario / -por orden de abecedario- / prenda a prenda van mirando / todo se los van probando". Nessa primera parte de $A$ lo bestia, destacam-se quatro feitiços que se relacionam com as disciplinas escolares que a criança vai estudando: o Conjuro primero (Benegas, 2011, p. 18) com a Língua ("Por un sustantivo / no duermo ni vivo. / por un predicado / me has cateado"); o Conjuro segundo (Benegas, 2011, p. 19) com a História e a Geografia, que "las va a estudiar tu tía", e as Ciências da Natureza, que "me dan dolor de cabeza"; o Conjuro tercero (Benegas, 2011, p. 20) com a Matemática ("Divido por cero, / te resto con saña, / cuando entres en clase/ serás una araña"); e o Conjuro cuarto (Benegas, 2011, p. 21) com o Inglês ("El pelo de un mono, yes / algo de ceniza, now / la luz de la moon por tres / y [...] ipobre profe de inglés!'). Aparece um feitiço final, o Conjuro quinto (Benegas, 2011, p. 22), no qual a criança caricatura o seu professor que "si me grita otra vez/con sus ojos de pez, su cabeza de foca / y graznidos de oca". A ilustração desses cincos "conjuros" demonstram uma atitude burlesca em relação às disciplinas escolares. Essas não possuem outra função que não seja a de ilustrar jogos de palavras que transgridem as formas comuns da semântica das palavras de cada um dos poemas. Um bom exemplo é a ilustração do Conjuro quinto, revelando um professor com gravata, mas com uma cabeça na qual se destaca uma densa barba e grandes olhos negros que parece que não veem nem controlam nada.

A segunda parte de A lo bestia, "Con la piel de gallina", trata das emoções das crianças: assim, o poema "Avestruz" (Benegas, 2011, p. 28) aborda o medo infantil ("cuando rompi los cristales / quería ser como tú, / esconderme bajo tierra / y no ver, ya más, la luz") e a necessidade de esconder-se debaixo da terra num buraco, como se vê a avestruz fazer. A ilustração de um longo pescoço escondido num buraco 
negro ajuda a criança, sobretudo no início, a representar na sua mente esse poema. Um segundo sentimento, que aparece no poema "La Hiena" (Benegas, 2011, p. 29), é o da alegria e do riso: "me río con dientes / de biena amarilla, / relucen brillantes, / me duelen la tripa". No desenho do poema, destacam-se, especialmente, o sorriso largo e os dentes brancos desse animal. A tristeza está representada e desenhada no poema "Lágrimas de cocodrilo"(Benegas, 2011, p. 30): "Tengo ganas de llorar: / lágrimas de cocodrilo". Aquilo que a ilustração salienta são as lágrimas capazes de chegar e transbordar uma pequena banheira até formar um charco de água. A impaciência é outro sentimento que se intui no poema "Cancioncilla de viaje" (Benegas, 2011, p. 33-34), no qual nunca se chega ao lugar desejado, dado que a rodovia é como uma serpente: "La carretera es culebra: / culebra que no camina. / Estirada en infinita / porque nunca se termina. / Estoy deseando llegar, poco a poco me impaciento". No seu desenho, aparece um caminho no qual se observa um sinal curioso com um rótulo estranho: montão de $\mathrm{km}$. Por último, o da raiva e do aborrecimento que aparecem no poema "Ánimoladas": (Benegas, 2011, p. 35-36) "Tres enormes hipopótamos / acampados tengo dentro, / cuando estoy muy enfadado / salen con gran estruendo". $\mathrm{Ou}$, no mesmo poema, "Un montón de monos locos / se alojan en mi garganta, / y cuando llega la rabia / gritan, escupen y saltan”. A sua ilustração é uma silhueta infantil na qual se destacam esses hipopótamos e macacos, correndo e saltando na garganta dessa.

$\mathrm{Na}$ terceira parte desse poemário, "Tres pies al gato", desfila um bestiário de animais humanizados. Destacamos, por exemplo, "Otorrinolaringato" (Benegas, 2011, p. 42), no qual o recurso à personificação alcança um grau máximo: "Médicos de la garganta / son estos raros felinos. / También oído y nariz / te curarán los mininos”. Esse poema surge acompanhado da ilustração de um gato, com uma grande cabeça, mas vestido com uma bata branca e um estetoscópio pendurado ao pescoço. Também no poema "Oviejas" (Benegas, 2011, p. 45), a partir de um simples jogo de palavras, aparece a personificação que humaniza todo o conteúdo do poema: "Son una especie de abuelas / que viven en el sofá. / Tejen los cuentos de lana / que luego te contarán". A imagem de uma avó, com um grande lenço na cabeça, mas com um corpo formado de lã, ajuda o leitor a imaginar essa figura humana com corpo de animal. Além disso, a lã que está tecendo está unida ao seu corpo por um fio muito fino. Por último, "Deslenguados" (Benegas, 2011, p. 48), que apresentam peixes faladores e insolentes que "bablan hasta en la sartén / o en tu tripa si los comes". A personificação desses animais está bem ilustrada com dois peixes de olhos enfadados e de cujas bocas saem até 18 "blablás".

A lo bestia é uma "selva de rimas", com ilustrações frescas, uma obra na qual se destacam o humor e a ternura de alguns animais comuns.

\section{EL POETA Y EL MAR, DE MARÍA WÉRNICKE}

Elpoeta y el mar (2012) é um álbum poético cartonado, publicado pela editora Kalandraka, escrito e ilustrado pela argentina María Wérnicke (1930). O título e a capa desse álbum são muito sugestivos, bem como o seu conteúdo textual, e, ainda, muito especialmente, o seu grafismo. Na capa, encontramos o poeta que, sentado em uma cadeira, escreve algo sobre uma mesa. Esse algo é o fruto do trajeto que 
se inicia a partir de uma pergunta: “Kali preguntó: / ¿Cómo es el mar?". E é aqui que começa uma grande viagem pelo mar para saber como ele é. Descobre uma paisagem maravilhosa e, sobretudo, um mar ondulante como a elasticidade das bailarinas, imenso como um gigante perante um pequeno escorpião, avassalador como um exército de soldados armados, mutável como a pele de um camaleão, feroz como o rugido de um leão, intrépido como um acrobata sobre uma fina corda, majestoso como a capa de um rei e enigmático como uma pessoa escondida e que apenas vê pelos olhos. Todas essas metáforas se expressam plasticamente, a partir de uma colagem de papéis na qual se destacam todas essas características do mar. No regresso da viagem, empreende um novo trajeto difícil de realizar: está sozinho, no seu escritório, diante de um papel em branco e terá que encontrar as palavras precisas e concretas para expressar poeticamente aquilo que viu, viveu e sentiu. A mensagem final desse álbum poético consiste em "afirmar" como é simultaneamente difícil e maravilhoso escrever literatura para um público capaz de sentir o que o poeta sente, quando compõe versos.

\section{CONSIDERAÇÕES FINAIS}

As obras aqui analisadas, e a partir das quais procuramos sinalizar algumas das soluções encontradas pelos ilustradores para conjugarem a sua linguagem com a linguagem poética, na tentativa de resolver questões de coerência (inter) textual, evidenciam um conjunto de singularidades textuais, paratextuais e visuais que possibilitam a sua filiação no subgênero da lírica para crianças que definimos como álbum poético infantil. Sinteticamente e retomando o que temos vindo a problematizar, esse objeto estético carateriza-se pela sua brevidade e concisão linguística, por um tipografismo inovador e, por vezes, até contracorrente, no qual a imagem predomina sobre a palavra (Sipe, 1998), pela sinergia e pela relação de convergência que, entre estas, se constata (Camargo, s. d.), bem como por uma refletida arquitetura de página, baseada em margens espaçosas. Toda essa construção facilita aos leitores iniciais - aqueles que leem imagens com eficácia ainda antes de "conhecerem" as palavras - uma leitura pausada que propicia uma experiência estética muito estimulante (Arizpe e Morag, 2004) e potencialmente fomentadora de competências de leitura, porque, na realidade, tanto o texto poético quanto a ilustração revestem-se de um sentido muito distante do literal. No âmbito da LIJ, a dimensão lírica é, muitas vezes, atenuada pela presença de elementos narrativos - elementos temporais e nexos causais, por exemplo - (Ramos, 2014, p. 114) que podem dificultar essa experiência estética. A presença de imagens nos álbuns poéticos é, desde logo, um elemento imprescindível para essa lírica infantil que quer impressionar os sentidos, em vez de contar uma história. Do que se trata, como ficou demonstrado a partir da análise de cada um dos álbuns poéticos selecionados, quer de edição/autoria portuguesa, quer de edição/autoria espanhola, é de assegurar a coerência e a unidade entre o texto e a imagem, para que ambos funcionem como uma unidade textual, em última instância, estética, coesa. Como afirma Camargo (1998, p. 97), "a ilustração é uma imagem que acompanha um texto e não seu substituto". Desde esse ponto de vista, a apropriação que o ilustrador realiza de cada um dos 
versos do poema é fundamental para assegurar essa coesão a que nos temos referido: "Crear imágenes capaces de interesar a un amplio público infantil no es cosa fácil, y lo es menos si esas imágenes han de ilustrar el texto, con lo cual la libertad creativa de su autor está condicionada a una creación anterior, la el autor literario"(Wensell, 2000, p. 152).

Essa potência imaginária, fruto da simbiose entre imagem e texto e que assoma em cada um dos poemários analisados, é a que possibilitará que a poesia infantil dos nossos dias supere a etapa que se cinge à dependência exclusiva dos jogos de palavras, do paralelismo e das repetições, dos recursos estruturais e não conceituais ou da colocação em verso de uma descrição ou uma história. Assim e para finalizar, o que carateriza o álbum poético é a sua vontade de sugerir e provocar impressões estéticas variadas, tudo muito para além das preocupações narrativas (Ramos, 2014, p. 114).

\section{REFERÊNCIAS}

Arizpe, E.; Morag, S. Lectura de imágenes: Ios niños interpretan textos visuales. México: F.C.E., 2004.

Benegas, M. A lo bestia. Madrid: República de Kukudrulu, 2011.

Bosch.E. ¿Cuántas palabras puede tener un álbum sin palabras? Ocnos, n. 8, p. 75-88, 2012. . Hacia una definición de álbum. Anuario de Investigación de Literatura Infantil y Juvenil, Vigo, n. 5, p. 25-45, 2007.

Camargo, L. A relação entre imagem e texto na ilustração de poesia infantil. [s.d.]. Disponível em: <http://www.unicamp.br/iel/memoria/Ensaios/poesiainfantilport.htm>. Acesso em: 15 out. 2014.

. Poesia infantil e Ilustração: estudo sobre "Ou isto ou aquilo" de Cecília Meireles [Dissertação]. Campinas: Universidade Estadual de Campinas; 1998.

Fierro, A. Los Meagrada. Barcelona: Bornova Ediciones, 2011 (Ilustração de Susana Rosique).

Godinho, S. O primeiro gomo da tangerina. Carcavelos: Planeta Tangerina, 2010 (Ilustração de Madalena Matoso).

Hanán Díaz, F. Leer y mirar el libro álbum: ¿un género en construcción? Bogotá: Norma, 2007.

Luján, J. Ser y parecer. México: SM/México, 2005 (Ilustração de Isol).

Martins, I. M. Pê de Pai. Carcavelos: Planeta Tangerina, 2006 (Ilustração de Bernardo Carvalho).

Mésseder, J. P. Palavra que voa. Lisboa: Caminho, 2005 (Ilustração de Gémeo Luís). Nodelman, P. The Hidden Adult. Defining Children's Literature. Baltimore: John Hopkins University Press, 2008.

Orozco Lòpez, M. T. El libro álbum: definición y peculiaridades. Sincronía, 51, 2009. Disponível em: <http://sincronia.cucsh.udg.mx/orozcofall09.htm>. Acesso em:15 out.2014. 
Ramos, A. M. Ilustrar la poesía para infancia: entre as rimas cromáticas e as metáforas visuais. Ocnos, n. 11, p. 113-130, 2014.

Rossetti, C.; Dickinson, E.; Goethe, J. W.; et al. Poemas a la luna. Barcelona: Edelvives, 2009 (Ilustração de Gianni De Conno).

Rubio, A. Almanaque Musical. Pontevedra: Kalandraka, 2012 (Ilustração de David Pintor). RuedA, E. F. La media naranja. Barcelona: Thule Ediciones, 2009 (Ilustração de E. Ferrándiz Rueda).

Schritter, I. La otra lectura: la ilustración en los libros para niños. Buenos Aires: Universidad Nacional del Litoral, 2005.

SiLva, S. R. Ilustração e poesia: para uma definição / caracterização do álbum poético para a infância. In: González Vida, R.; Moleón Viana, M. A.; González Castro, C. In: Congreso Internacional Arte, Ilustración y Cultura Visual en Educación Infantil y Primaria: Construcción de Identidades, 1., 2010, Granada.Actas... Granada: Universidad de Granada, 2011. p. 565-570.

Sipe, L. R. How pictures Books Work: Semiotically Framed Theory of Text-Picture Relationships. Children's Literature in Education, n. 29, p. 97-108, 1989.

Soares, L. D. O mar. Lisboa: Gatafunho, 2008 (Ilustração de Pedro Sousa Pereira).

Vieira, A. A charada da bicharada. Lisboa:Texto, 2008 (Ilustração de Madalena Matoso).

Wensell, U. El papel de las ilustraciones en la difusión de los libros para niños. In: Cerrillo, P. C.; García Padrino, J. (Orgs.). Presente y futuro de la Literatura Infantil. Cuenca: Cepli, 2000. p. 151-156.

WÉrnicke, M. El poeta y el mar. Pontevedra: Kalandraka, 2012 (Ilustração de Maria Wérnicke).

\section{SOBRE OS AUTORES}

Sara Reis da Silva é doutora em literatura para a infância pela Universidade do Minho (Portugal). Professora da mesma instituição.

E-mail: sara_silva@ie.uminho.pt

Moisés Selfa Sastre é doutor em filología hispánica pela Universitat de Lleida (Espanha). Professor da mesma instituição.

E-mail: mselfa@didesp.udl.cat

Recebido em 06 de junho de 2015

Aprovado em 26 de novembro de 2015 